\title{
Ethical and bioethical aspects concerning the disclosure of medical information for a fair reason
}

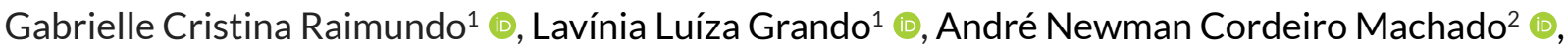 \\ Matheus Oliveira² (1), Fábio Roberto Cabar ${ }^{3 *}$ (1)
}

\section{SUMMARY}

OBJECTIVE: The objective of this study was to emphasize the importance of legal and bioethical knowledge in maintaining medical confidentiality, especially in situations when there is a diagnosis of HIV infection.

METHODS: A literature review of studies published in the Scientific Electronic Library Online and National Library of Medicine databases was performed. Sixteen studies available in full, online, and free, published between 2010 and 2020, were selected.

RESULTS: The studies highlighted that, despite the ethical duty to breach confidentiality for the protection of third parties, many doctors are reluctant to reveal this secret due to the power of stigmatization and social discrimination related to the diagnosis of HIV infection, which affects integrity, counseling, and capability to treat patients.

CONCLUSION: HIV diagnosis implies bioethical and legal questions. Respect for medical confidentiality is a matter to be discussed, as there is a need to protect the privacy of the patient, at the same time the responsibility to preserve the health of others.

KEYWORDS: Confidentiality. Bioethics. HIV. Human rights.

\section{INTRODUCTION}

According to article 73 of the Brazilian Code of Medical Ethics, physicians are prohibited from disclosing information obtained in the exercise of their professional activities and must maintain confidentiality in any situation, except for a fair reason, a legal duty, or written consent from the patient. If this ethical command is violated, the professional is subject to administrative sanctions applied by the Brazilian Federal Council of Medicine. Also, the Brazilian Penal Code, in its article 154, provides for the preservation of professional secrecy, criminalizing the conduct of breaking the secret ${ }^{1,2}$.

However, the same professional code provides exceptions to this imperative of secrecy. Situations in which there is express authorization from the patient, the law requires the disclosure of information (such as in cases involving suspicion of mistreatment of children and adolescents in which the Child and Adolescent Statute determines the communication of information to the Council Guardianship), or when there is just reason, confidentiality can (and should) be breached. Accordingly, in cases where the patient has an infectious disease, in which there is a risk of contamination from third parties, there is a need for communication from third parties, at the risk of contagion, morbidity, and mortality of these people 3 . In this sense, the Brazilian Penal Code itself, in its article 130, provides for a penalty of 3 months to 1 year of detention and a fine for those who "expose someone, through sexual intercourse or any libidinous act, to contagion of venereal disease, of who knows or should know that he is contaminated."

The Brazilian Federal Council of Medicine, aware of these issues, published Resolution 1665/2003 which provides that professional secrecy must be strictly respected in relation to patients with the HIV virus, but still noting that this secrecy can be broken for a fair reason ${ }^{3,4}$.

In contrast, the American Medical Association advises physicians to comply with disease notifications but preserve the confidentiality of the patient's condition. Thus, when a patient's illness represents a threat to another identifiable individual, the physician's duty is to notify public health authorities and communicate the risk to third parties, without, however, revealing the identity of the infected person. The justification for such a recommendation is to guarantee protection to HIV-infected patients since there is still great social discrimination ${ }^{3,5}$.

This study aims to identify in the literature the different approaches related to medical confidentiality and discussions

\footnotetext{
${ }^{1}$ Universidade do Sul de Santa Catarina - Palhoça (SC), Brazil.

${ }^{2}$ Centro Universitário, Faculdade das Américas - São Paulo (SP), Brazil.

${ }^{3}$ Universidade de São Paulo, Faculdade de Medicina, Departamento de Obstetrícia e Ginecologia - São Paulo (SP), Brazil.

*Corresponding author: fabio.cabar@hc.fm.usp.br

Conflicts of interest: the authors declare there is no conflicts of interest. Funding: none.

Received on October 14, 2021. Accepted on October 16, 2021.
} 
about exceptions to disclosure of information for a fair reason, especially when there is a risk to the health of third parties.

\section{METHODS}

This study was carried out from a query made on the Scientific Electronic Library Online and US National Library of Medicine data platforms using the Health Sciences Descriptors. The key words used were "HIV," "AIDS," crossing them with the terms "confidentiality," "bioethics," "medical confidentiality," and "medical ethics," in Portuguese, English, and Spanish. Boolean operators were also used to increase the quality of the results: "HIV and medical ethics," "Breach of medical confidentiality," "HIV and medical confidentiality," and "HIV and confidentiality."

Studies that were published between 2011 and 2020 were included. Duplicate articles, that were published outside the stipulated period, and that did not meet the research objectives were excluded.

\section{RESULTS}

Sixteen studies were selected which constituted two main research focuses: (i) ethical and bioethical dilemmas in the management of patients with HIV infection and (ii) violation of medical confidentiality for a fair reason.

In the analysis of the selected articles, approaching the panorama of ethical and bioethical dilemmas in the management of HIV-positive patients, the power of stigmatization and social discrimination in the care of these patients can be highlighted, which directly affects their integrity, the stimulus for realization testing, counseling, and treatment of the disease. From this perspective, Mataboge and collaborators pointed out the inefficiency of the public health system in South Africa, which creates tensions between individuals with acquired immunodeficiency syndrome and physicians, whether due to the lack of clinical and laboratory approach to the disease, or the conditions of continuity of treatments, due to inadequate ethical and moral training of these health professionals, added to society's lack of information about the dilemmas related to HIV infection, which directly affects the impact of the infection in the country ${ }^{6}$. In line with these findings, Dapaah and Senah pointed out that stigma is the main underlying reason that explains the reluctance of many people to undertake voluntary testing and accept medical advice, which would lead to adequate and early antiretroviral treatment. For this population, infection would be associated with death and not with sexual promiscuity, so that stigmatized patients believe that the disease is incurable and that their pain and suffering are shameful ${ }^{7}$.
Arrivillaga-Quintero highlighted tensions and barriers related to adherence to antiretroviral treatments by infected women in Colombia, showing that the problems faced by women are even greater than those faced by men; according to the author, the low adherence verified in the country is structurally determined by the health system, either by the lack of rights and comprehensive health care, or by the violation of confidentiality of information or by social discrimination. It was evident that women affected by HIV infection are stigmatized, being objects of rejection because of this diagnosis and face more discrimination than men; that the possible breach of confidentiality by professionals generates even greater tensions, making adherence to treatment difficult ${ }^{8}$.

Domínguez and collaborators discussed the application of the bioethical principles of autonomy, beneficence, non-maleficence, justice, in addition to the challenges of diagnosing HIV infection to these principles. According to them, in these circumstances, the physician is faced with the dilemma of choosing between the individualistic ethics typical of his deontology and a series of social needs that demand other types of moral behavior, even though in practice, the obligation, both moral and legal, to inform the spouse/partner of the patient's situation, and communication to the health authorities is also mandatory. From the authors' perspective, violations of medical confidentiality can discourage patients from testing and adhering to treatments due to fear of discrimination and exposure to others. So, it is the responsibility of health professionals to provide comprehensive care to these patients and strictly observe the ethics and dilemmas that arise in their daily lives?.

In a study by Silva and Ayres, these authors confirmed that, in case the patient refuses to inform his/her partner about the diagnosis, it is the duty of health professionals to disclose the information. In situations of conflict, the physician must be guided by ethical and legal principles because, despite the importance of preserving confidentiality with the patient, in this case, it is necessary to protect the sexual partner from contamination by the virus ${ }^{10}$.

According to the Opinion of the Regional Council of Medicine of Rio de Janeiro number 16/92, prepared with the assistance of the Technical Advisory Committee for the Prevention, Control, and Treatment of AIDS, the intensity of the harm caused to the patient by the breach of confidentiality must be evaluated. Thus, if the harm caused to the patient by breaking this confidentiality is greater than that potentially caused to the partner if he were to be infected, the medical confidentiality should be maintained ${ }^{11}$. Villas-Bôas highlighted key points of the duty of professional secrecy in health, supporting the necessary trust in the doctor-patient relationship. In this 
issue, the exceptions of breach of confidentiality for a fair reason in cases of HIV diagnosis are addressed. The disclosure is expected to take place in a restricted scope, so that the epidemiological care and conduct do not represent unnecessary exposure and source discrimination and embarrassment to the patient.

From another point of view, Burger dealt with issues related to the lack of registration of HIV infection as the underlying cause of death on the death certificate, justifying the issues of patient confidentiality and undue exposure of the diagnosis, which could impact the issues of life insurance, funeral policy claims, beliefs, etc. Therefore, the author stated that, in these administrative matters, a decision must be taken which balances the consequences of not breaking medical confidentiality and the consequences of disclosing the diagnosis to the sexual partners of the deceased ${ }^{12}$.

\section{DISCUSSION}

Specifically, when it comes to the diagnosis of HIV infection, several studies address the difficulties of maintaining medical confidentiality when stigma, prejudice, and social discrimination have taken root in society. Other authors emphasized that the main cause of stigma would be the fact that the disease is associated with death and not sexual promiscuity. In view of this, a study carried out in Ghana argues that HIV-positive patients are discriminated because of the belief that the disease is incurable and that their fears and feelings are said to be shameful ${ }^{6}$. According to a study by Arrivillaga-Quintero, it is the influence of social class on this theme; according to the author, women in higher social positions experience greater stigma when compared with women in less privileged social positions. This fact would increase the fear of the breach of confidentiality by women who are socially better placed, which would make them opt for private services, to the detriment of public services, in order not to be enrolled in the system. This would reveal the patients' lack of trust in the health professionals responsible for providing care in public health services ${ }^{8}$.

From another angle, Bernal and Álvarez traced the trajectory of the ethical dilemmas of confidentiality and the handling of the HIV diagnosis in the face of notifications of positive results identified to the health departments and the controversies related to the exposure of sexual partners. Again, the authors highlighted the difficulties of reconciling professional secrecy by physicians and the health care team with the ethical requirement to avoid harm to those people who, kept in strict professional secrecy, can become infected, and are in danger of dying. However, they also reinforce the guidelines of the American Medical Association that professional secrecy admits exceptions as long as the doctor prevents the spread of contagious diseases but recognizes the right to confidentiality of people with HIV. According to the authors, the physician should try to persuade the infected patient to report the case to the sexual partner, and if unsuccessful, the authorities should be informed; if further steps are not taken, the physician must finally inform and advise that third person is at risk ${ }^{13}$.

According to the Brazilian Ministry of Health (2013), the AIDS acts destructively on the immune system, having high severity and great relation to the appearance of opportunistic infections and neoplasms. Therefore, the ethical and bioethical discussion of the flexibility of professional confidentiality is essential, when there is a possible risk to the sexual partner's life, to avoid new transmissions, and to promote awareness and treatment of the disease. The questions about the maintenance of medical confidentiality increase when there is a risk to the health of other people. Again, the feasibility of placing HIV infection as the primary cause on the death certificate is discussed and the fact should be disclosed to the funeral policy insurer, the life insurance company, and the sexual partner. In this bias, the Federal Council of Medicine recommends that, even after death, medical secrecy must be respected, again except in cases of compulsory notification, situations that involve risk to others, and mistreatment of minors. Therefore, according to the Federal Council of Medicine of Brazil, if the patient's diagnosis represents a threat to another identifiable individual, the doctor's duty ranges from notifying public health authorities to communicating the risk to third parties, without revealing the person's identity source. Thus, the breach of confidentiality is justified, given that medical secrecy, undeniably, serves to protect the HIV-infected patient from social discrimination, with the proviso that it should not contribute to the spread of the virus.

Finally, Claudia Mora presented a study suggesting that counseling, pretesting, and obtaining specific informed consent for the exam represent barriers to acceptance of the test, as they increase anxiety in patients. Thus, counseling would only be recommended at the time of delivery of the result, with the aim of reducing the stigma in relation to testing, and minimizing the constraints arising from the spontaneous search for health services ${ }^{14}$.

\section{CONCLUSIONS}

The importance of knowledge of ethical, bioethical, and legal norms related to the maintenance of professional secrecy is evident, especially considering the impact of disclosure of confidentiality in cases of HIV infection, as there 
are implications for social discrimination in stigmatized patients, which can discourage patients and directly affect the demand for health services, anti-HIV testing, treatment, and medical reliability, given all the feelings of doubts and fears rooted in society.

\section{REFERENCES}

1. Código de Ética Médica. Conselho Federal de Medicina. Resolução CFMn 2.217/2018. modificadapelas Resoluções CFMnº 2.222/2018 e 2.226/2019. Brasília: Conselho Federal de Medicina, 2019.

2. Lima SMFS, Silva SMM, Neves NMBC, Crisostomo, LML. Avaliação do conhecimento de estudantes de medicina sobre sigilo médico. Rev Bioét. 2020;28(1):98-110. https://doi.org/10.1590/198380422020281372

3. Salvadori M, Hahn GV. Confidencialidade médica no cuidado ao paciente com HIV/aids. Rev Bioét. 2019;27(1):153-63. https:// doi.org/10.1590/1983-80422019271298

4. Ministério da Saúde. Secretaria de Vigilância em Saúde. Programa Nacional de DST e Aids. Implicações Éticas do Diagnóstico e da Triagem Sorológica do HIV / Secretaria Vigilânciaem Saúde, Programa Nacional de DST e Aids. Brasília: Ministério da Saúde, 2004.

5. American Medical Association. Report of the council on ethical and judicial affairs. Amendment to E-2.23, "HIV Testing" (Resolution 517, A-09), 2010.

6. Mataboge MS, Peu MD, Chinuoya M, Rikhotso R, Ngunyulu RN, Mulaudzi FM. Healthcare workers' experiences of HIV testing in Tshwane, South Africa. Curationis. 2014;37(1):1170. https://doi. org/10.4102/curationis.v37i1.1170

7. Dapaah JM, Senah KA. HIV/AIDS clients, privacy, and confidentiality; the case of two health centres in the Ashanti Region of Ghana. BMC Med Ethics. 2016;17(1):41. https://doi.org/10.1186/s12910-0160123-3

8. Arrivillaga-Quintero, M. Análisis de las barreras para la adherencia terapéutica en mujeres colombianas con VIH/sida: cuestión de

\section{AUTHORS' CONTRIBUTIONS}

GCR, LLG: Conceptualization, Data curation, Visualization, Writing - original draft. FRC: Formal Analysis, Investigation, Supervision, Validation. FRC, GCR, LLG: Methodology, Project administration. ANCM, FRC, MO: Writing - review \& editing.

derechos de salud. Salud pública Méx. 2010;52(4):350-6. Available from: https://saludpublica.mx/index.php/spm/article/view/6985.

9. Brito Sosa G, Iraizoz Barrios AM. Enfoque bioético de los pacientes portadores del VIH, y de médicos y enfermeros de la atención secundaria sobre el VIH/SIDA. Rev Cubana Med Gen Integr. 2011;27(2):217-31. Available from: https://bit. ly/2ByJ5hz.

10. Silva NEK, Ayres JRCM. Strategies for disclosing HIV status to sexual partners and their relationship to healthcare provision. Cad Saúde Pública. 2009:25(8):1797-806. https://doi.org/10.1590/ S0102-311X2009000800016

11. Conselho Regional de Medicina do Rio de Janeiro. Comissão Técnica de Assessoramento para a Prevenção, Controle e Tratamento da AIDS. VIEIRAW. Parecer CRMERJ N. 16/92. Rio de Janeiro, 1992. Available from: http://www.portalmedico.org.br/pareceres/crmrj/ pareceres/1992/16 1992.htm.

12. Burger EH, Groenewald P, Rossouw A, Bradshaw D. Atestado médico de óbito na África do Sul - seguindo em frente. S Afr Med J. 2015;105(1):27-30. Available from: http://www. scielo.org.za/scielo.php?script=sci_arttext\&pid=SO25695742015000100016\&lng=en. http://dx.doi.org/10.7196/ SAMJ.8578.

13. Martínez Bernal I, Rimada Álvarez YT, Vera Santos C. Problemas bioéticos que se desprenden en la atención a las personas viviendo con VIH/sida. Rev Med Electrón. 2010;32(2). Available from: https://bit.ly/2R6OPoz.

14. Pereira PPG. Monteiro S, Villela W, organizadores. Estigma e Saúde. Rio de Janeiro: Editora Fiocruz; 2013. Cien Saude Colet. 2015;20(4);1307-8. https://doi.org/10.1590/141381232015204.00092014 